\title{
Weather variability in a decade and its current impact on airborne pollen and spores in Nsukka, Nigeria
}

\author{
1Dimphna Nneka Ezikanyi, ${ }^{2}$ Gloria Sakwari and ${ }^{3}$ Peter Burt \\ ${ }^{1}$ Ebonyi State University, Department of Applied Biology, Faculty of Science, Abakaliki ,Nigeria \\ ${ }^{2}$ Muhimbili University of Health and Allied Sciences, Department of Environmental and Occupational Health, Public Health, Tanza nia \\ ${ }^{3}$ University of Greenwich, Department of Agriculture, Health and Environment, London
}

Correspondence Author: Dimphna Nneka Ezikanyi , Ebonyi State University, Department of Applied Biology, Faculty of Science, Abakaliki ,Nigeria E-mail:dimphna.nneka@yahoo.com

Received date: 12 November 2018, Accepted date: 10 January 2019, Online date: 25 January 2019

Copyright: (C) 2019Dimphna Nneka Ezikanyiet al., This is an open-access article distributed under the terms of the Creative Commons Attribution License, which permits unrestricted use, distribution, and reproduction in any medium, provided the original author and source are credited.

\begin{abstract}
Pollen and spores are propagules released from plants and fungi for the sole purpose of reproduction. Their abundance and constituent predispose them as major triggers of allergy. However, their dispersal and seasonality are determined by biological activities and their response to weather variability. Studies on weather variability in a decade and the impact of current weather on airborne pollen and spores in Nsukka (South- East Nigeria) were carried out. The aim of the study was to assess weather variability in a decade and relationship between present weather variables and airborne pollen and spores concentration in ambient atmosphere in the study area. Weather parameters were collected from the Meteorological Centre in the study area. Aero samples were collected monthly using a Tauber-like pollen sampler modified to sample $1.52 \mathrm{~m}$ above ground. Samples were sieved through $100 \mu$ mesh wire gauze to filter off large organic and soil particles. The liquid with suspended palynomorphs was centrifuged at $\mathbf{2 5 0 0}$ revolutions per minute (rpm) for 5 mins and subjected to acetolysis in other to remove tissues and organic debris from surface of pollen and spores. Weather parameters chronicle profound weather variability in a decade in the region, which has led to the present shift in onset of rainy season, shift in peak periods of rain and off -season rain. Change in weather brought by the onset of rainfall triggered sporulation and dispersal of diverse spores into the ambient air, especially potent allergenic spores with the spores of Ovularia, Bispora, Curvularia, Nigrospora, Helminthosporium . These "hydrophilic fungi" were abundant in the rainy season, though in varying quantity. Atopic individuals should take prophylactic approaches prior to onset of rainy periods to avoid fungal hypersensitivity at the rainy period.
\end{abstract}

Key words: Allergy, fungal spores, pollen, weather parameters, Nsukka Nigeria

\section{INTRODUCTION}

Allergic diseases are triggered or exacerbated by contact or inhalation of pollen, fungal spores, dust mites, insect debris, animal epithelial cells, and some foods and substances [1]. People are exposed throughout life to allergens directly (externally) or after they enter their bodies (by inhalation or ingestion) [2]. Of these, airborne pollen and spores are the most dominant, pervasive, respirable and potent sources of allergen present in the indoor and outdoor atmosphere [3,4].

Pollen and spores allergen belong to Type One hypersensitivity [5]. Their proteins are immune modulatory substances, which play crucial roles in the sensitization and/or exacerbation of allergies such as seasonal allergic rhinitis, eczema/dermatitis, conjunctivitis, rhinoconjuctivitis, asthma, bronchial constriction and obstruction, pollinosis and aspergillosis [6]. It has been clearly demonstrated that exposure to indoor and outdoor airborne fungal spores, hyphal fragments or metabolites can cause a variety of respiratory diseases and also associated with poor control of asthma [7,8,9].

In the $21^{\text {st }}$ Century, allergic disorders have become a health problem of global significance, affecting all ages and ethnic backgrounds [10]. For the past 40 years the prevalence of asthma has in general increased and is still increasing worldwide in parallel with other indices of allergy [11]. The increase in allergic disorders, such as allergic rhinitis, bronchial asthma and atopic dermatitis covers up to $30 \%$ of the world's population [12]. About $10-30 \%$ of the world's population is affected by allergic rhinitis and more than 300 million are affected by asthma [13]. 
Pollen and spore liberation involve active and passive processes and depends on rainfall, wind speed, wind direction, humidity, temperature and circadian pattern (darkness and sunlight) $[14,15]$. The quantity and seasonality depend in large part on plant responses to climatic and meteorological variables [16]. Pollen production varies however from species-to species, site- to site and year-to-year [17]. It has been suggested that global climate change could alter the concentrations, distributions, dispersion patterns and allergenicities of pollen and spores in the environment in ways that could further increase the prevalence of allergic diseases $(16,18)$. It has also been demonstrated that plants produce greater number of pollens with increased allergenicity under high temperature [19]. Changing environment due to climate change was discovered to potentiate their allergenic effect [20].

Studies on spatial distribution of airborne pollen and spores in the atmosphere, and the potential impacts of climate change on these, are therefore an important aid for the effective management, treatment and diagnosis of pollen and spores allergies [15]. The use of suitable medications before the expected increase in atmospheric pollen counts will reduce the severity of allergic reactions.

Within Nigeria, a high prevalence of allergic rhinitis (63.9\%) in individuals with asthma in Ilorin was reported [21]. However, its prevalence among respiratory unit patients in Benin city Nigeria was $6.6 \%$, and lower compared to similar results in Sweden (9\%), Australia (10.7\%) and Norway (9.3\%) [22]. Increase in allergic rhinitis, wheezing, diagnosed asthma, shortness of breath and chest tightness were discovered among students in Babcock University, Ogun State, Nigeria in 2015 [23].

The present study was undertaken in Nsukka (South-East Nigeria) from January- June 2017, to examine the spatial distribution and abundance of airborne pollen and spores, correlation of airborne pollen and spores with weather parameters were also studied.

\section{Study area and sample collection}

\section{MATERIALS AND METHODS}

The study was conducted at the University of Nigeria Nsukka (South-East Nigeria) from January to June 2017. Nsukka is a suburban town located at an elevation of $419.4 \mathrm{~m}$ a.s.1. (06 69' N; 007 33 'E) (Figure 1). The Anambra Plains bound the town on the east and the Udi highlands on the south-west [24]. Tauber-like pollen trap modified by attaching stand to achieve a height of $1.52 \mathrm{~m}$ above ground was employed for collection of aerosamples. A solution made of glycerol (50 ml), formaldehyde (10 ml) and phenol $(5 \mathrm{ml})$ was prepared and poured into the trap. The recipient solutions were collected monthly for the period of six months. Samples were sieved through $100 \mu \mathrm{m}$ mesh wire gauze to filter off large organic particles and centrifuged at 2500 revolution per minute for 5 minutes to recover the aerospore residues according to [25].

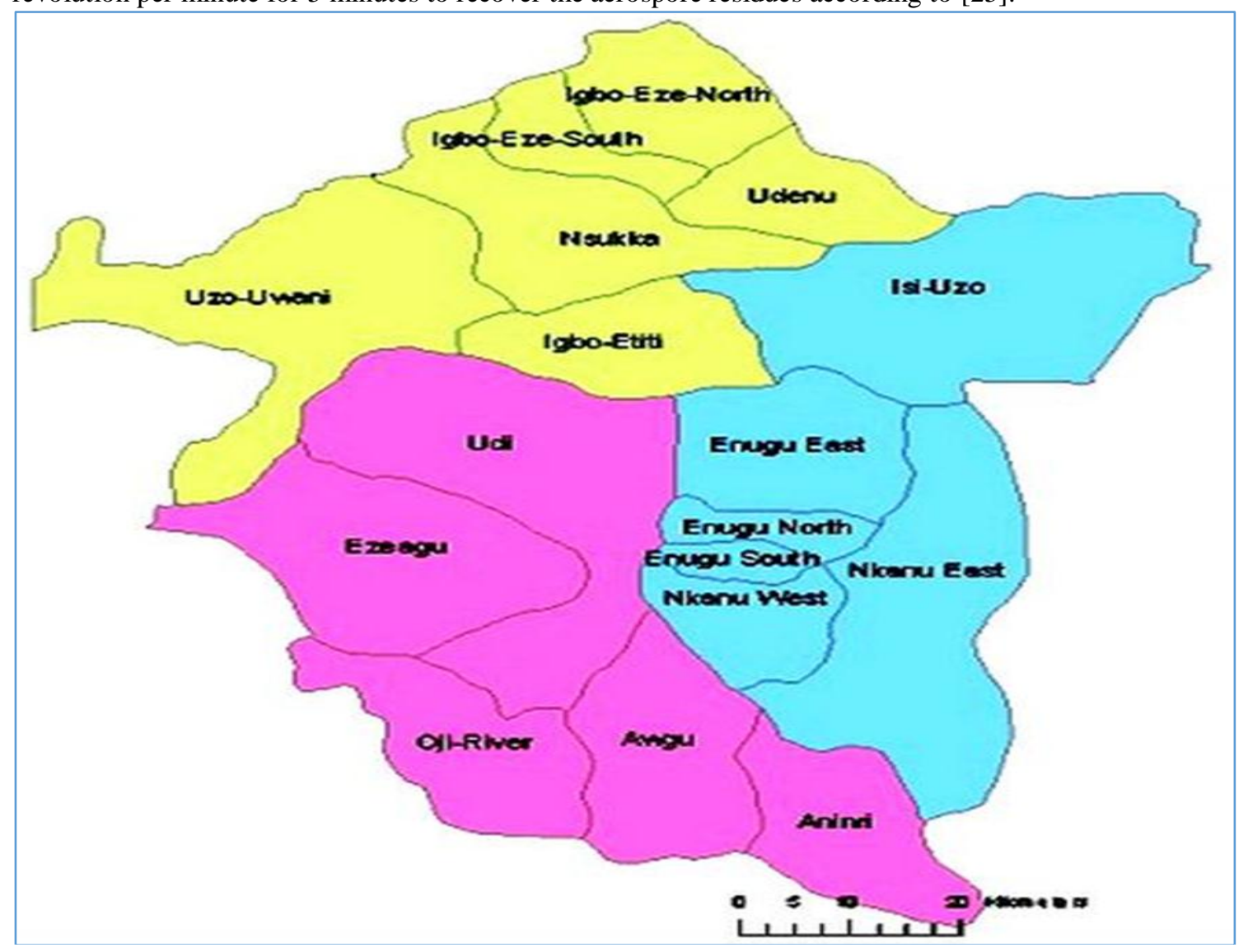

Figure 1: Map of Enugu State, Nigeria showing the study area (World Gazette, 2011).

The residues were washed three times with distilled water and were acetolyzed in other to remove most of the tissues, organic debris, protein, lipids and carbohydrate from the surface of the pollen and spores [26]. Recovered residues were stored in vials with two drops of glycerine for preservation. Temporary slides were prepared and examined using a light microscope, equipped with MVV3000 Future WinJoe digital camera (Future Optics Science and Technology, Hangzhou, China). Identification was 
based on comparison with a reference collection of pollen slides, and descriptions and photomicrographs of pollen and spores using books and journals [27, 28, 29]. The pollen and fungal spores obtained were counted monthly and expressed as a frequency by species. Meteorological data of rainfall $(\mathrm{mm})$, temperature $\left({ }^{\circ} \mathrm{C}\right)$, wind speed $(\mathrm{knot})$ and direction, and relative humidity $(\%)$ were obtained from Meteorological Centre, Agriculture Department, University of Nigeria Nsukka, near the sampling site. The data obtained from decadal weather variables were analyzed using the SPSS statistical package Version 20 (SPSS Inc. Chicago, Illinois USA). Correlation co-efficient were generated to examine the relationship between pollen, fungal spores frequency and current weather variables.

\section{Pollen and spore data}

\section{RESULTS}

Compared to the amount of pollen, the aerobiota was dominated by fungal spores. A total of 6,500 spores, consisting of 89 types were recorded, of which there were 5,827 fungal spores (89.6\% of the catch), whilst pollen constituted 475 individual grains $(7.31 \%$ of the total catch). The remaining catch comprised diatoms $(173,2.7 \%)$ and fern spores $(3,0.05 \%)$.

Anemophilous pollen dominated entomophilous ones and the majority of the pollen were dispersed from trees. Pollen released from Poaceae, Casuarina equisetifolia and Elaeis guineensis were most abundant (Table 1). More airborne pollen grains were caught in the drier months (January- March, 351) than in rainy months (April-June, 121). The input of pollen in the month of June within the rainy season was dominated by grasses (Table 1).

Fungi belonging to phylum Ascomycota were more preponderant (Table 2). Some spores were persistently present in the atmosphere from January to June: those of Nigrospora, Epicoccum, Hansfordia, Curvularia, Spadicoides, Alternaria alternata and also diatoms. Most spores prevalent during the drier months dominated in the month of March. March had first record of rain $(1 \mathrm{~mm})$ in 2017, though was a dry month. The first rain evoked sporulation of fungi leading to increased preponderant of airborne fungal spores both qualitatively and quantitatively. The atmosphere became highly infiltrated with innumerable spores of Curvularia, Bispora and Ovularia at a rainfall record of $204 \mathrm{~mm}$ in June 2017(Fig 2; Plates 2a \& 2b).

The total fungal spores correlated positively with monthly rainfall and humidity but negatively with temperature. Among the dominant fungal spores, Ovularia and Curvularia spores correlated positively with rainfall and relative humidity, others such as Nigrospora and Helminthosporium correlated negatively with rainfall (Table 3). All dominant fungal spores, except Bispora, correlated positively with relative humidity. There was a negative though not significant correlation between total pollen count with current rainfall and relative humidity. All dominant pollen except Poaceae correlated negatively with rainfall and humidity (Table 4).

Weather Variability in a Decade in Nsukka, Nigeria

A shift in the onset and peak of rainy season, expansion of the rainy season and off-season rain were recorded from 2007 to the present (Figure 3). From 2012 to the present, especially, the amount of rainfall has increased. Seasonal rainfall peaks have moved from July-August to August and this has led to an expansion of the rainfall period from the usual six months of active rain in the region to 7 months, beginning from 2009 to the present. More recently, 2016 and 2017 witnessed a shift in the onset of rainfall from March to May. Off-season rain, of increasing amounts, has been recorded in November from 2012 to 2016(Figure 3). Temperature has varied, rising and falling though within a very narrow range. In a decade, the average annual temperature varied from $26.88{ }^{\circ} \mathrm{C}$ - $27.88{ }^{\circ} \mathrm{C}$ (Figure 4). Average annual humidity has not been steady within the past decade, they varied within $72.25 \%-77.33 \%$ miminum and maximum respectively (Figure 5). Average annual wind speed has varied within a narrow range from 4.27 knot (minimum) in 2015 to 6.33 knot (maximum) in 2008. Most years had a higher record of wind speed in December to March and August and a decline in June (Fig. 6). Wind direction from 2007- 2011 has been predominantly South West and West from 2012, wind direction has tilted to predominantly West in most months of the year (Table 5).

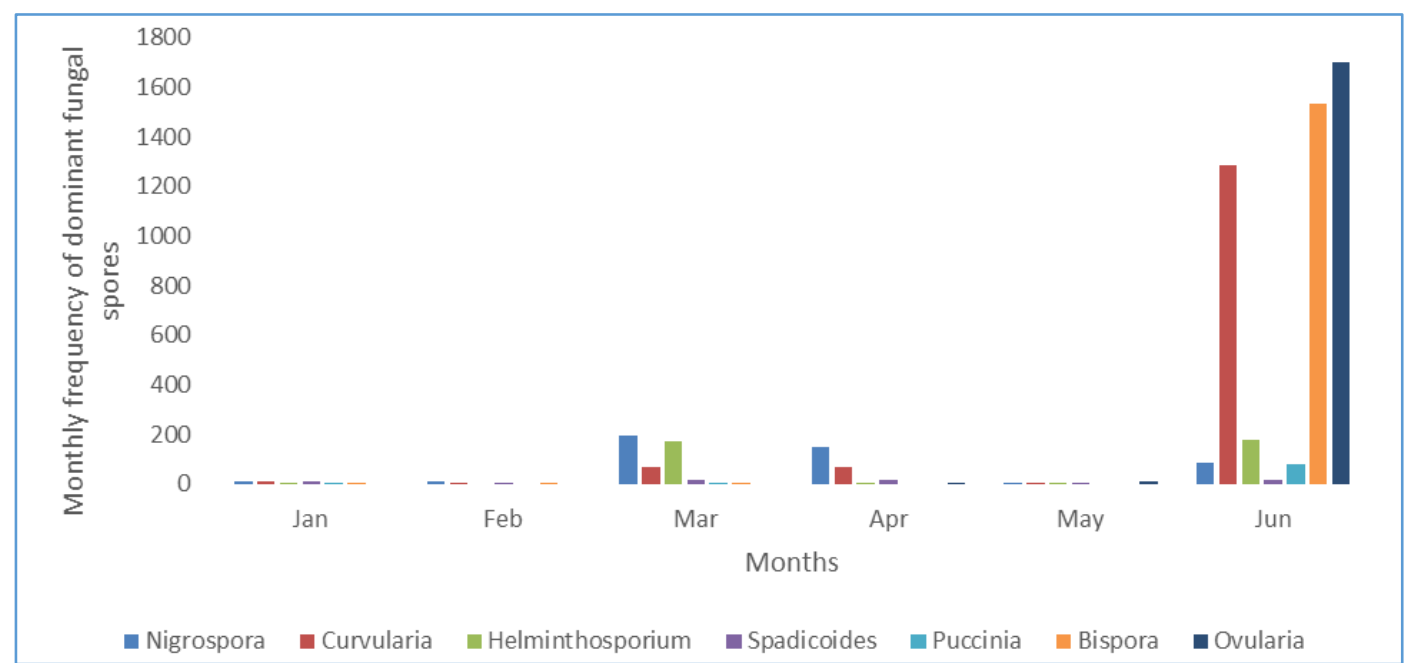

Fig. 2: Frequency of dominant airborne fungal spores in Nsukka,Nigeria from January-June,2017 


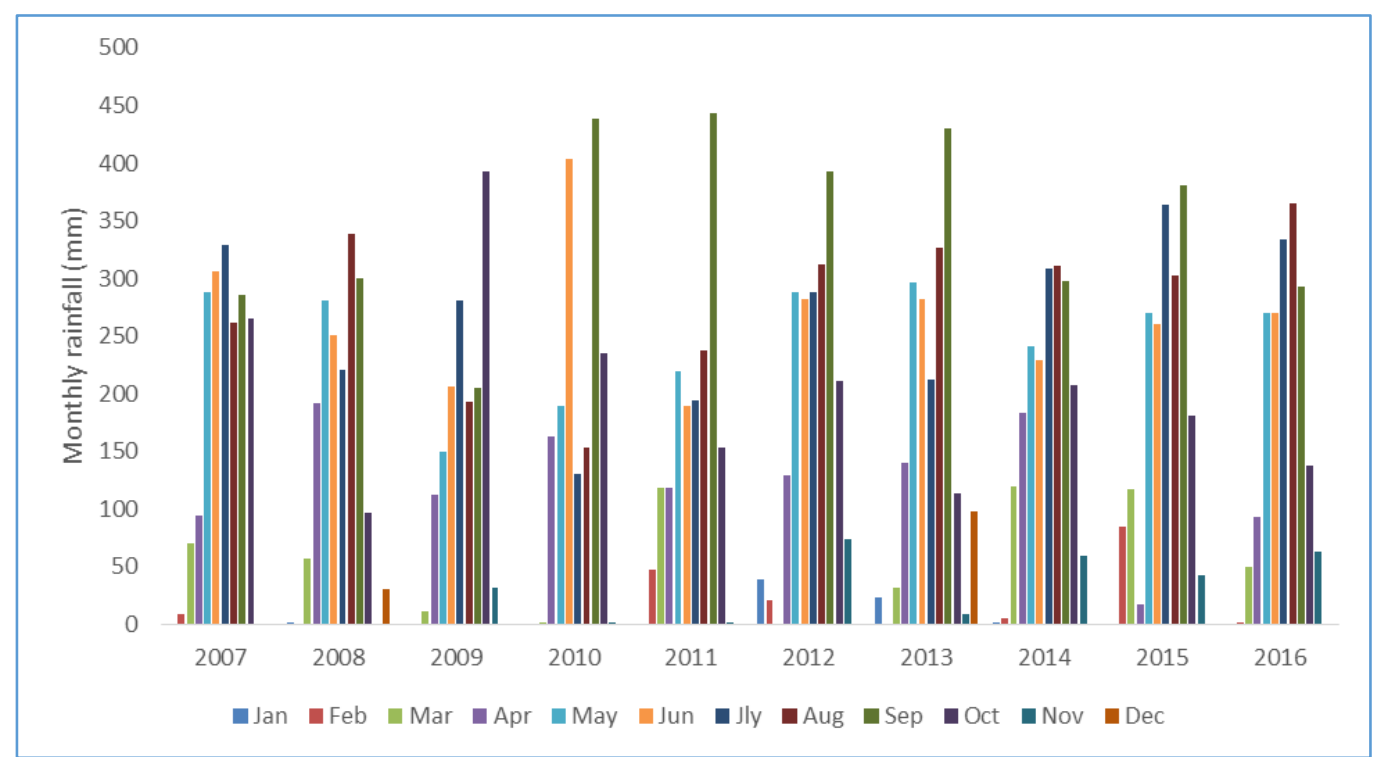

Fig. 3: Monthly rainfall (mm) variation in a decade in Nsukka, Nigeria from $2007-2016$

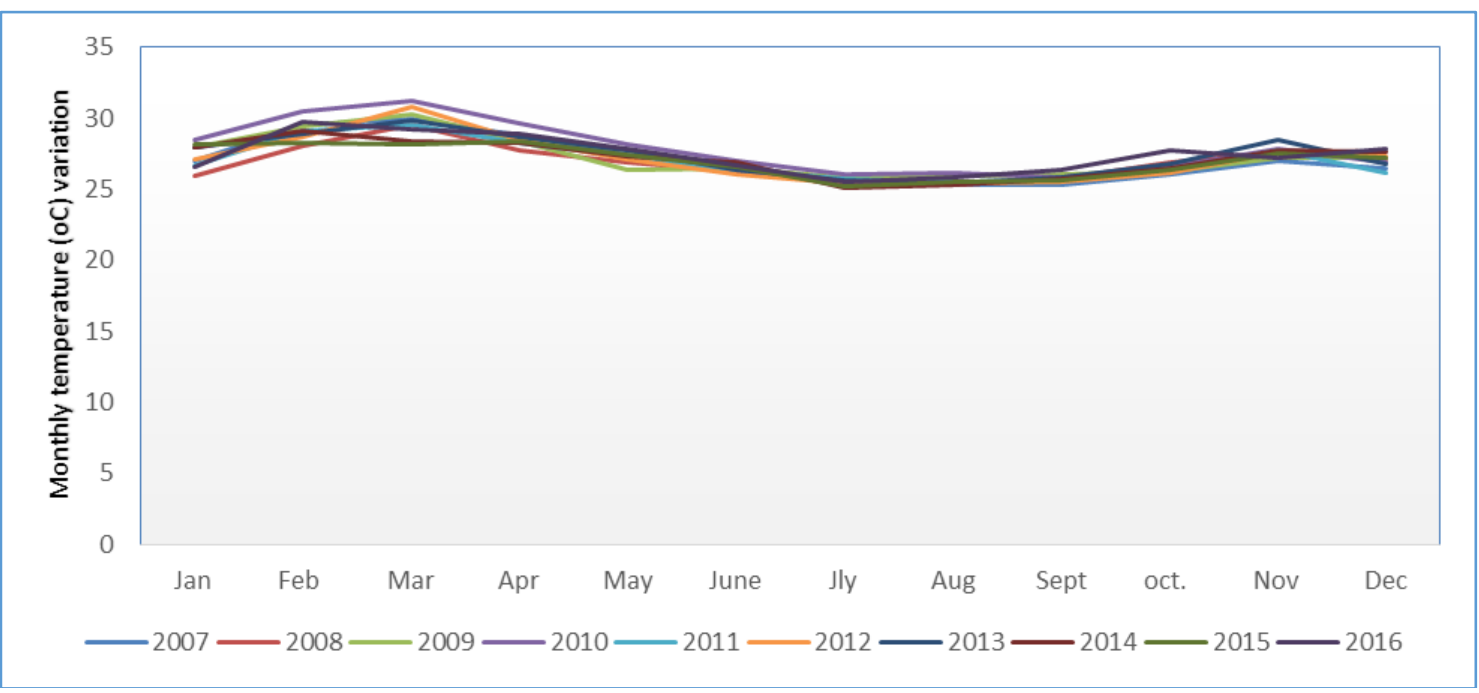

Fig. 4: Monthly temperature $\left({ }^{\circ} \mathrm{C}\right)$ variation in a decade in Nsukka, Nigeria from 2007-2016

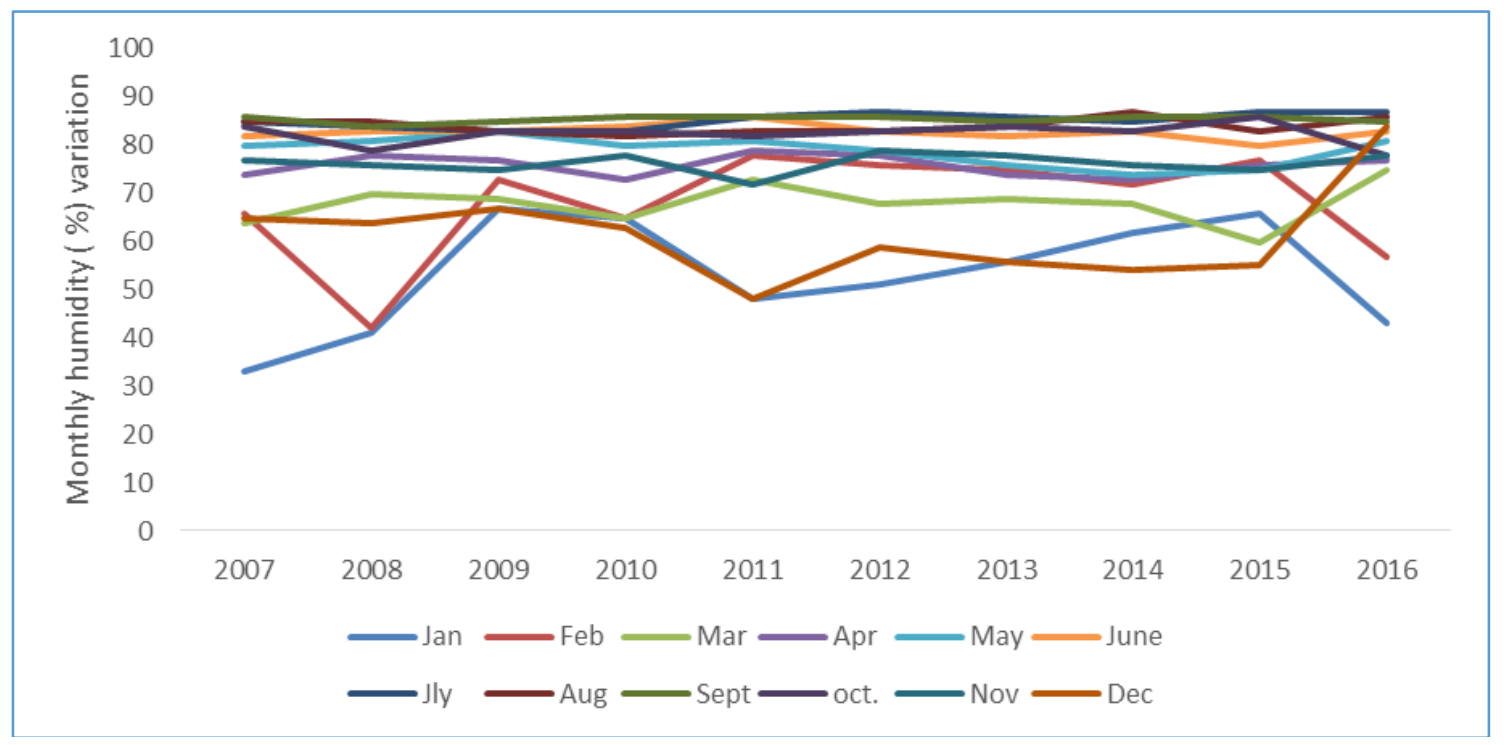

Fig. 5: Monthly humidity (\%) variation in a decade in Nsukka, Nigeria from 2007-2016 


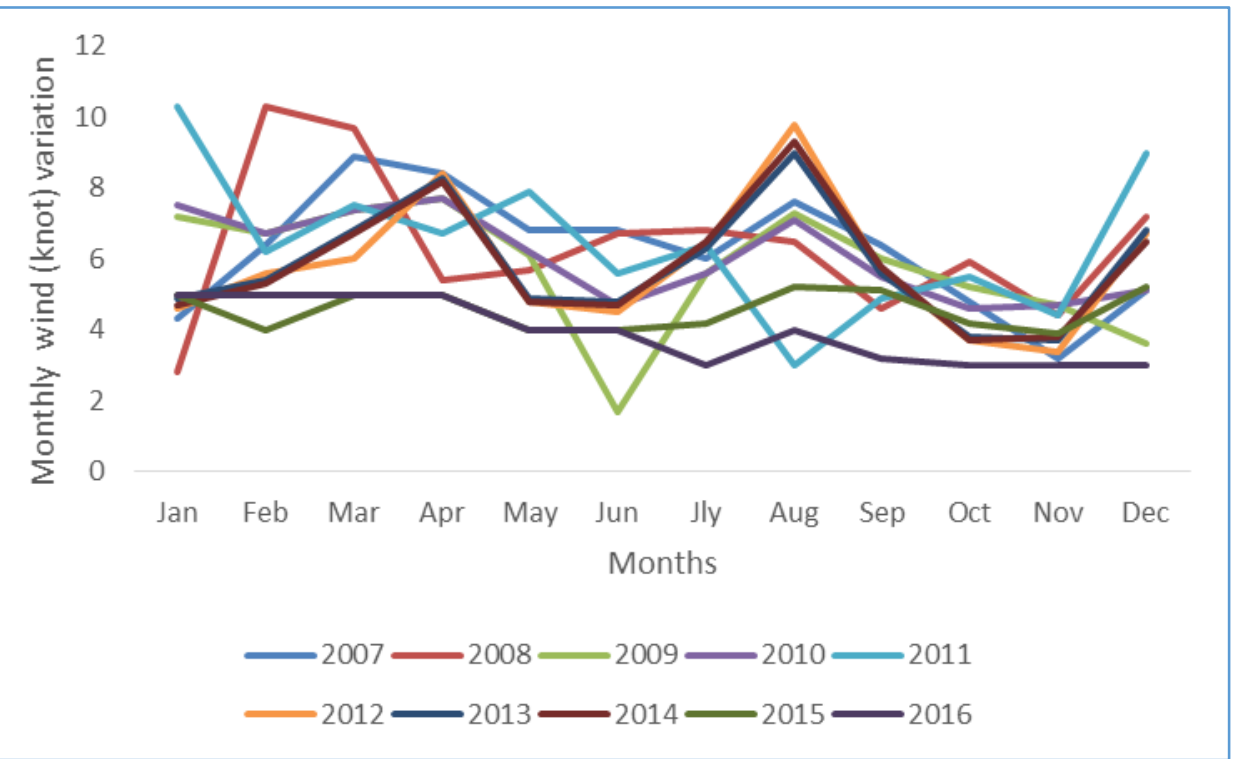

Fig. 6: Monthly wind (knot) variation in a decade in Nsukka, Nigeria from 2007-2016

Table 1: Pollen Grains Frequency in NSUKKA, Nigeria from January to June 2017

\begin{tabular}{|c|c|c|c|c|c|c|c|c|c|c|}
\hline S. No & Pollen & Habit & Jan & Feb & Mar & Apr & May & Jun & Total & $\%$ \\
\hline 1. & Elaeis guineensis & Tree & 42 & 12 & 14 & 1 & 0 & 3 & 72 & 15.42 \\
\hline 2. & Amarath./Cheno. & Herb & 18 & 6 & 1 & 1 & 0 & 0 & 26 & 5.57 \\
\hline 3. & Alchornea cordiforlia & Shrub & 10 & 7 & 16 & 1 & 0 & 1 & 35 & 7.50 \\
\hline 4 & Syzygium guineense & Tree & 3 & 1 & 0 & 0 & 0 & 0 & 4 & \\
\hline 5 & Pentaclethra macrophylla & Tree & 3 & 2 & 4 & 0 & 3 & 18 & 28 & 6.00 \\
\hline 6 & Tapinanthus & Shrub & 1 & 0 & 0 & 0 & 0 & 0 & 1 & 0.21 \\
\hline 7 & Poaceae & Grass & 20 & 21 & 6 & 3 & 6 & 46 & 102 & 21.84 \\
\hline 8 & Eugenia nodiflora & Tree & 2 & 0 & 0 & 0 & 0 & 0 & 2 & 0.43 \\
\hline 9 & Casuarina equisetiforlia & Tree & 69 & 36 & 1 & 0 & 0 & 0 & 106 & 22.70 \\
\hline 10 & Cyperus sp. & Herb & 10 & 2 & 0 & 0 & 0 & 0 & 12 & 2.57 \\
\hline 11 & Cocos nucifera & Tree & 1 & 0 & 8 & 1 & 0 & 1 & 10 & 2.40 \\
\hline 12 & Hymenocardi aacida & Shrub & 8 & 1 & 0 & 0 & 3 & 6 & 18 & 3.85 \\
\hline 13 & Lannea welwitschii & Tree & 1 & 0 & 0 & 0 & 0 & 0 & 1 & 0.21 \\
\hline 14 & Albizia sp. & Tree & 1 & 1 & 2 & 1 & 2 & 1 & 8 & 1.71 \\
\hline 15 & Parkia biglobosa & Tree & 2 & 0 & 0 & 0 & 0 & 0 & 2 & 0.43 \\
\hline 16 & Irvingia wombolu & Tree & 1 & 0 & 0 & 0 & 0 & 0 & 1 & 0.21 \\
\hline 17 & Terminalia $\mathrm{sp}$ & Tree & 0 & 1 & 2 & 1 & 0 & 0 & 4 & 0.86 \\
\hline 18 & Pallinia pinnata & Climber & 0 & 1 & 0 & 0 & 0 & 3 & 4 & 0.86 \\
\hline 19 & Acanthaceae & Shrub & 0 & 0 & 3 & 0 & 0 & 0 & 3 & 0.64 \\
\hline 20 & Olax subscoipoides & Tree & 0 & 0 & 1 & 0 & 0 & 0 & 1 & 0.21 \\
\hline 21 & Morus sp. & Tree & 0 & 0 & 0 & 3 & 3 & 3 & 3 & 0.64 \\
\hline 22 & Phyllanthus sp. & Shrub & 0 & 0 & 0 & 1 & 0 & 0 & 1 & 0.21 \\
\hline 23 & Talinum triangulare & Herb & 0 & 0 & 0 & 0 & 0 & 0 & 1 & 0.21 \\
\hline 24 & Vernonia & Herb & 0 & 0 & 0 & 0 & 0 & 0 & 1 & 0.21 \\
\hline 25 & Cissus & Shrub & 0 & 0 & 0 & 0 & 0 & 1 & 1 & 0.21 \\
\hline 26 & Lannea acida & Tree & 0 & 0 & 0 & 0 & 0 & 4 & 3 & 0.64 \\
\hline 27 & Anthocleista sp. & Tree & 0 & 0 & 0 & 0 & 0 & 1 & 1 & 0.21 \\
\hline 28 & Khaya senegalensis & Tree & 0 & 0 & 1 & 0 & 0 & 0 & 1 & 0.21 \\
\hline 29 & Allophylus africanus & Shrub & 0 & 0 & 4 & 0 & 0 & 0 & 4 & 0.86 \\
\hline 30 & Morus sp. & Tree & 0 & 0 & 1 & 0 & 0 & 0 & 1 & 0.21 \\
\hline \multirow[t]{2}{*}{31} & Adansonia digitata & Tree & 0 & 0 & 1 & 0 & 0 & 0 & 1 & 0.21 \\
\hline & Total & & 189 & 95 & 67 & 14 & 14 & 93 & 475 & \\
\hline
\end{tabular}


Table 2: Spores frequency in NSUKKA, Nigeria from January to June 2017

\begin{tabular}{|c|c|c|c|c|c|c|c|c|c|c|}
\hline S. No & Spores & & Jan & Feb & Mar & Apr & May & Jun & Total & $\%$ \\
\hline 1. & Venturia & Ascomycota & 1 & 2 & 23 & 3 & 1 & 29 & 59 & 0.80 \\
\hline 2. & Nigrospora & Ascomycota & 13 & 9 & 193 & 49 & 7 & 85 & 356 & 5.91 \\
\hline 3. & Epicoccum & Ascomycota & 1 & 1 & 3 & 7 & 1 & 2 & 15 & 0.25 \\
\hline 4 & Spadicoides & Ascomycota & 19 & 1 & 22 & 34 & 3 & 18 & 97 & 0.53 \\
\hline 5 & Sporidesmium & Ascomycota & 1 & 1 & 0 & 0 & 0 & 0 & 2 & 0.03 \\
\hline 6 & Hansfordia & Ascomycota & 1 & 2 & 5 & 1 & 3 & 0 & 12 & 0.03 \\
\hline 7 & Cordana & Ascomycota & 2 & 1 & 0 & 3 & 0 & 2 & 8 & 0.13 \\
\hline 8 & Curvularia & Ascomycota & 11 & 6 & 70 & 67 & 7 & 1285 & 1446 & 24.0 \\
\hline 9 & Helminthosporium & Ascomycota & 4 & 0 & 171 & 1 & 1 & 1 & 178 & 2.95 \\
\hline 10 & Trichocladium & Ascomycota & 1 & 0 & 1 & 0 & 2 & 8 & 12 & 0.20 \\
\hline 11 & Cladosporium & Ascomycota & 2 & 0 & 2 & 4 & 0 & 3 & 11 & 0.18 \\
\hline 12 & Sporoschisma & Ascomycota & 2 & 1 & 0 & 0 & 0 & 0 & 3 & 0.05 \\
\hline 13 & Spilocea & Ascomycota & 2 & 1 & 0 & 0 & 0 & 0 & 3 & 0.05 \\
\hline 14 & Puccinia & Basidiomycota & 1 & 2 & 11 & 9 & 2 & 83 & 108 & 1.79 \\
\hline 15 & Pithomyces & Ascomycota & 1 & 0 & 16 & 6 & 0 & 26 & 49 & 0.81 \\
\hline 16 & Alternaria & Ascomycota & 0 & 1 & 1 & 0 & 0 & 7 & 11 & 0.18 \\
\hline 17 & Cercospora & Ascomycota & 0 & 2 & 2 & 0 & 0 & 1 & 5 & 0.08 \\
\hline 18 & Torulla & Ascomycota & 0 & 1 & 1 & 3 & 0 & 2 & 7 & 0.12 \\
\hline 19 & Tetraploa & Ascomycota & 0 & 0 & 2 & 2 & 1 & 8 & 13 & 0.15 \\
\hline 20 & Ustilago & Basidiomycota & 0 & 0 & 3 & 6 & 1 & 25 & 35 & 0.58 \\
\hline 21 & Oidium & Ascomycota & 0 & 0 & 2 & 0 & 0 & 6 & 8 & 0.13 \\
\hline 22 & Alternaria alternata & Ascomycota & 1 & 1 & 24 & 6 & 1 & 4 & 37 & 0.61 \\
\hline 23 & Bipolaris & Ascomycota & 0 & 0 & 3 & 0 & 0 & 0 & 3 & 0.05 \\
\hline 24 & Papularia & Ascomycota & 0 & 0 & 1 & 0 & 0 & 1 & 2 & 0.03 \\
\hline 25 & Dactylaria & Ascomycota & 0 & 0 & 1 & 1 & 0 & 5 & 7 & 0.12 \\
\hline 26 & Helicomina & Ascomycota & 0 & 0 & 1 & 0 & 0 & 0 & 1 & 0.01 \\
\hline 27 & Apiospora & Ascomycota & 0 & 0 & 2 & 0 & 0 & 0 & 2 & 0.03 \\
\hline 28 & Bispora & Basidiomycota & 1 & 2 & 3 & 0 & 0 & 1534 & 1540 & 25.6 \\
\hline 29 & Ulocladium & Ascomycota & 1 & 0 & 2 & 0 & 0 & 0 & 3 & 0.05 \\
\hline 30 & Puccinia canadensis & Basidiomycota & 0 & 0 & 1 & 2 & 0 & 0 & 3 & 0.05 \\
\hline 31 & Chalara & Basidiomycota & 0 & 0 & 3 & 2 & 0 & 0 & 5 & 0.08 \\
\hline 32 & Harknessia & Basidiomycota & 1 & 2 & 7 & 0 & 3 & 0 & 5 & 0.08 \\
\hline 33 & Dreschlera & Ascomycota & 0 & 0 & 2 & 1 & 0 & 11 & 14 & 0.23 \\
\hline 34 & Blastomyces & Ascomycota & 0 & 0 & 0 & 1 & 0 & 0 & 1 & 0.01 \\
\hline 35 & Balanum & Ascomycota & 0 & 0 & 0 & 1 & 0 & 0 & 1 & 0.01 \\
\hline 36 & Venturia inequalis & Ascomycota & 0 & 0 & 0 & 0 & 1 & 0 & 1 & 0.01 \\
\hline 37 & Pucciniopsis & Ascomycota & 0 & 0 & 0 & 0 & 0 & 13 & 13 & 0.22 \\
\hline 38 & Ovulariopsis & Ascomycota & 0 & 0 & 0 & 0 & 0 & 5 & 5 & 0.08 \\
\hline 39 & Beltrania & Ascomycota & 0 & 0 & 0 & 0 & 0 & 2 & 2 & 0.03 \\
\hline 40 & Monilia & Ascomycota & 0 & 0 & 0 & 0 & 0 & 1 & 1 & 0.01 \\
\hline 41 & Candida & Ascomycota & 0 & 0 & 0 & 0 & 0 & 1 & 1 & 0.01 \\
\hline 42 & Phomopsis & Ascomycota & 0 & 0 & 0 & 0 & 0 & 1 & 1 & 0.01 \\
\hline 43 & Diplocladiella & Ascomycota & 0 & 0 & 1 & 0 & 0 & 0 & 1 & 0.01 \\
\hline 44 & Trichocladium & Ascomycota & 0 & 0 & 1 & 0 & 0 & 0 & 1 & 0.01 \\
\hline 45 & Smut fungi & Basidiomycota & 0 & 0 & 1 & 4 & 0 & 0 & 5 & 0.08 \\
\hline 46 & Paathramaya & Ascomycota & 0 & 0 & 3 & 3 & 0 & 0 & 6 & 0.10 \\
\hline 47 & Hyphae fragment & Ascomycota & 0 & 0 & 3 & 3 & 0 & 0 & 6 & 0.10 \\
\hline 48 & Total fungal spores & & 68 & 39 & 594 & 216 & 49 & 4863 & 5829 & \\
\hline 49 & Diatoms & Ochrophyta & 57 & 45 & 25 & 26 & 10 & 9 & 173 & 2.87 \\
\hline \multirow[t]{3}{*}{50} & Fern & Pteridiophyta & 1 & 1 & 0 & 1 & 0 & 0 & 3 & 0.05 \\
\hline & Indeterminate & & 3 & 8 & 11 & 0 & 0 & 0 & 22 & 0.37 \\
\hline & Total & & 129 & 93 & 606 & 222 & 51 & 4956 & 6,025 & \\
\hline
\end{tabular}


Table 3: Correlation coefficients between frequency of dominant fungal spores and weather variables

\begin{tabular}{|c|c|c|c|c|}
\hline S/N & Dominant fungal spores & R & T & R.H \\
\hline 1 & Ovularia & 0.690 & -0.139 & 0.308 \\
\hline 2 & Bispora & 0.720 & -0.181 & -0.426 \\
\hline 3 & Curvularia & 0.704 & -0.180 & 0.387 \\
\hline 4 & Nigrospora & -0.100 & 0.407 & 0.227 \\
\hline 5 & Helminthosporium & -0.322 & 0.552 & 0.227 \\
\hline & Total fungal spores & 0.690 & -0.139 & 0.308 \\
\hline
\end{tabular}

$P=0.01$ level (2 tailed)

R- mean monthly rainfall (mm), T-mean monthly temperature (oC), R.H-relative humidity (\%)

Table 4: Correlation coefficients between frequency of dominant pollen and weather variables

\begin{tabular}{|c|c|c|c|c|}
\hline S/N & Dominant pollen & R & T & R.H \\
\hline 1 & Elaeis guinensis & -0.267 & 0.578 & -0.622 \\
\hline 2 & Poaceae & 0.515 & 0.059 & -0.876 \\
\hline 3 & Casuarina equisetiforlia & -0.483 & 0.488 & -0.689 \\
\hline 4 & Total pollen & -0.267 & 0.578 & -0.622 \\
\hline
\end{tabular}

$P=0.01$ level (2 tailed)

R- mean monthly rainfall (mm), T-mean monthly temperature (oC), R.H-relative humidity (\%)

Table 5: Monthly variation of wind direction in a decade in Nsukka, Nigeria from 2007-2016

\begin{tabular}{|c|c|c|c|c|c|c|c|c|c|c|c|c|c|}
\hline S. No & Year & Jan & Feb & Mar & Apr & May & June & Jly & Aug & Sep & Oct & Nov & Dec \\
\hline 1. & 2007 & NW & $\mathrm{W}$ & $\mathrm{W}$ & SW & SW & SW & $\mathrm{SW}$ & $\mathrm{W}$ & $\mathrm{W}$ & SW & SW & $\mathrm{W}$ \\
\hline 2. & 2008 & $\mathrm{NE}$ & NW & SW & SW & $\mathrm{W}$ & SW & $\mathrm{W}$ & $\mathrm{W}$ & $\mathrm{W}$ & $\mathrm{W}$ & SW & SW \\
\hline 3. & 2009 & $\mathrm{~W}$ & SW & SW & SW & SW & SW & SW & SW & $\mathrm{W}$ & $\mathrm{W}$ & SW & $\mathrm{E}$ \\
\hline 4 & 2010 & $\mathrm{~W}$ & $\mathrm{~W}$ & SW & SW & SW & SW & $\mathrm{W}$ & SW & SW & SW & $S$ & NW \\
\hline 5 & 2011 & NW & SW & SW & SW & SW & SW & W & W & $\mathrm{W}$ & $S$ & $\mathrm{E}$ & NW \\
\hline 6 & 2012 & $\mathrm{~W}$ & $\mathrm{~W}$ & $\mathrm{~W}$ & SW & $\mathrm{W}$ & $\mathrm{W}$ & $\mathrm{W}$ & $\mathrm{W}$ & $\mathrm{W}$ & $\mathrm{W}$ & $\mathrm{W}$ & W \\
\hline 7 & 2013 & $\mathrm{~W}$ & $\mathrm{~W}$ & SW & $S$ & $S$ & $\mathrm{~W}$ & $\mathrm{~W}$ & $\mathrm{~W}$ & $\mathrm{~W}$ & $S$ & $\mathrm{~S}$ & $\mathrm{~W}$ \\
\hline 8 & 2014 & $\mathrm{~W}$ & $\mathrm{~W}$ & SW & $\mathrm{S}$ & $\mathrm{S}$ & $\mathrm{W}$ & $\mathrm{W}$ & $\mathrm{W}$ & $\mathrm{W}$ & $\mathrm{W}$ & $\mathrm{W}$ & $\mathrm{NE}$ \\
\hline 9 & 2015 & $\mathrm{~W}$ & $\mathrm{~W}$ & $\mathrm{~S}$ & SW & $\mathrm{W}$ & SW & $\mathrm{W}$ & $\mathrm{W}$ & $\mathrm{W}$ & $\mathrm{W}$ & $\mathrm{S}$ & $\mathrm{NE}$ \\
\hline 10 & 2016 & NW & $\mathrm{W}$ & $\mathrm{W}$ & $\mathrm{W}$ & SW & $\mathrm{W}$ & $\mathrm{W}$ & $\mathrm{W}$ & $\mathrm{W}$ & SW & NW & NW \\
\hline
\end{tabular}

NW- North west, W- West, SW-South west, S-South, E-East

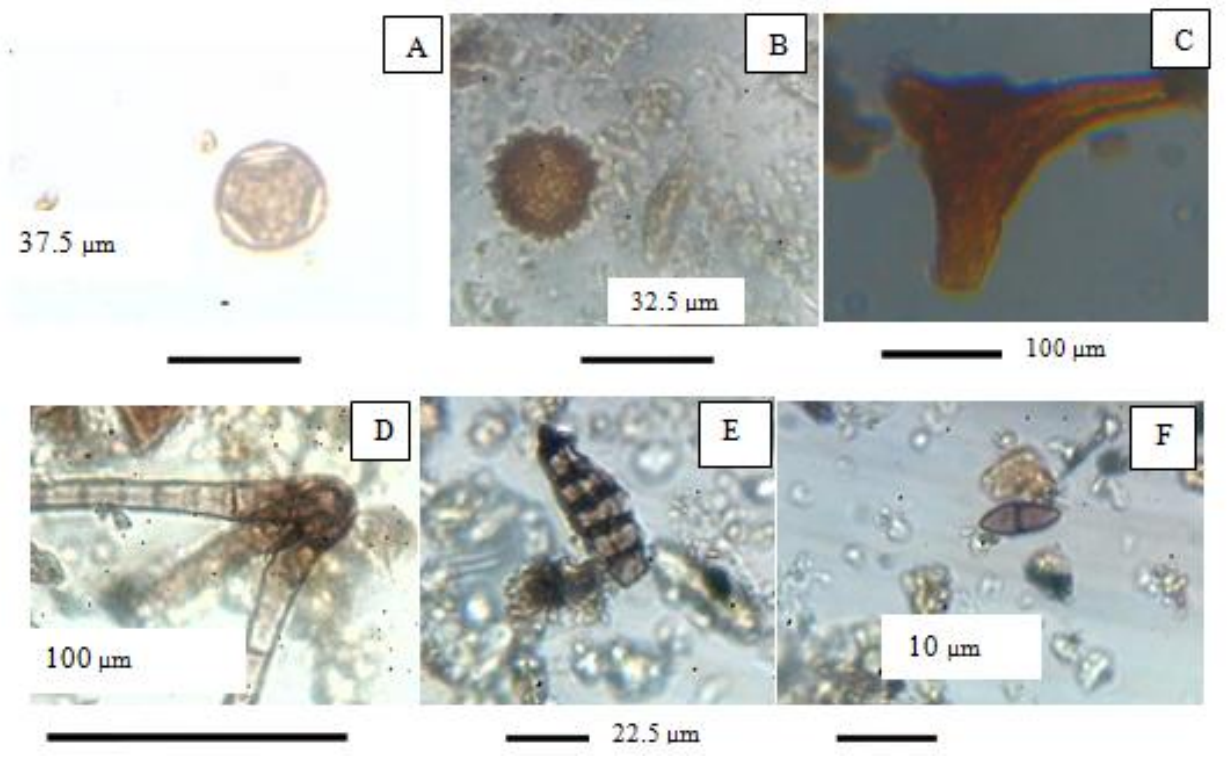

Plate 1:Photomicrographs of some pollen; A. Casuarina equisetiforlia, B. Vernonia C. Tapinanthus Fungal spores; D. Tetraploa, E. Alternaria F. Cladosporium. All Mag 400x 


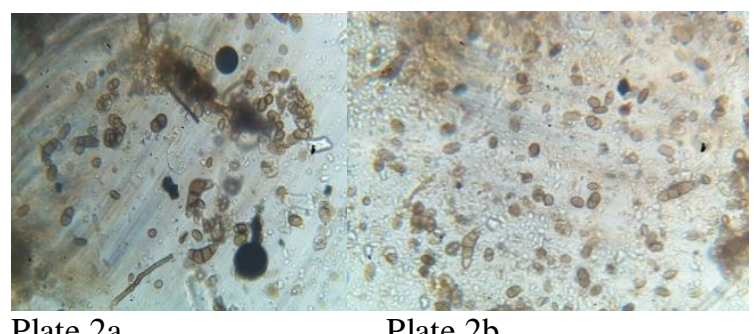

Plate $2 \mathrm{a}$

Plate $2 b$

Plate $2 \mathrm{a} \& 2 \mathrm{~b}$ : Typical component of the wet weather fungal sporesMag 400x

\section{DISCUSSION}

Airborne pollen trapped reflected the plants which were in flower within the study period at the surrounding vegetation of the study area. Pollen released from dominant trees, shrubs and grasses indicated the mosaic of lowland rainforest and secondary grassland ecotype, as shown by previous research [30]. More pollen morphotypes occurred in January. This was influenced by pollination activities of mainly Elaeis guinensis and Casuarina equisetifolia plants and partly due to a higher wind action, as a result of north east wind which usually prevails in harmattan period in Nsukka during December- January [31]. More pollen was dispersed from anemophilous taxa; Elaeis guineensis, Amarathaceae/Chenopodiaceae, Alchornea cordiforlia, Pentaclethra macrophylla, Poaceae and Casuarina equisetifolia. These plants produce and release enormous quantities of pollen to compensate for the inefficiency of wind in pollination ecology, they also have a stronger aerodynamism compared to the entomophilous counterpart [32].

Poaceae (grass) pollen were the most non-arboreal pollen which dominated among anemophilous pollen in the study area. They were present throughout the study period but became preponderant in June. Several aerobiological studies in Nigeria have reported preponderance of Poaceae pollen almost throughout the year. In a similar work, persistent dominance of grass pollen was recorded in the atmosphere of South East Nigeria [24]. Poaceae pollen was also recorded in the atmosphere of Northcentral Nigeria from February-June 2016 [25]. The persistence presence of Poaceae pollen is related to the long pollen season of most species. Poaceae pollen include both the wild and cultivated types and are not segregated in aerobiological studies because of similarities in their morphological features, though cultivated species have been reported to possess a larger grain size than wild species [33]. Most species have been confirmed to be allergenic in humans. Heteropogon, a wild genus in Poaceae was found to possess a highly allergenic protein and showed a positive skin test reaction in humans [34]. Despite these reports, the clinical importance of species of Poaceae in exacerbation of allergies in symptomatic patients has not been established in Nigeria.

Total pollen was found to correlate positively though not significant with current temperature and negatively with current monthly rainfall and humidity. The finding agrees with previous studies in Nigeria $[24,25]$ who also found that airborne pollen concentration correlated positively with temperature and negatively with rainfall in the atmosphere of South-east and Northcentral Nigeria, respectively.

There is limited work on seasonal fungal spores concentration in relation with weather parameters in Nigeria. Spores of fungi were the major components of the aerosamples and were more concentrated in the atmosphere in the dry month (March) which received first rain and in June which had a higher record of monthly rainfall. Onset of rainfall was very profound in influencing sporulation of many suspended fungal spores in the region. Increase in rainfall amount was also associated with infiltration of airborne spores in the ambient atmosphere. Such composition of spores could be a major cause of allergenic diseases in susceptible individuals. The correlation of total fungal spores counts and most dominant fungal spores with monthly relative humidity and rainfall indicated a linkage between sporulation and rainy period and underscores the role of rain in facilitating fungal spores release. On the contrary, total fungal spores count and most dominant spores correlated negatively, though not significantly, with temperature. In a similar study, the same association between fungal spores with rainfall, relative humidity and temperature in North- central Nigeria was obtained [25].

Most fungal spores recorded in the present research have been reported as the major component of the aerospora in some parts of the world. In a similar work in Fortaleza, Brazil, Curvularia, Cladosporium, Pithomyces among others dominated the outdoor environment [35]. Some spores recorded in the studied region have been documented in the literature as potent allergen carriers. Sensitization of Alternaria and Cladosporium species are related to development of asthma and rhinitis [36]. The spores of Alternaria, Cladosporium,Curvularia and Epicoccum elicited highest skin reactivity in patients despite disparity in spore's concentration [37].

Nsukka lies within the equatorial region of South-East Nigeria and has experienced average annual rainfall and temperature within $132.05 \mathrm{~mm}-169.94 \mathrm{~mm}$ and $26.88{ }^{\circ} \mathrm{C}-27.88^{\circ} \mathrm{C}$ respectively within the past decade (2007-2016). Its climatic status differs profoundly from northern Nigeria, which is drier and South-west Nigeria which is wetter. Climatic data primarily revealed an extension and higher amount of rainfall which gradually encroached into the early dry season in the area. Previous study found significant positive correlation of temperature with time and indicated that rainfall and temperature have increasing trend over time [38]. In a study carried out for a period of 105 years (1901-2005) in Nigeria, increasing intensity of rainfall was also found in coastal areas of Southern Nigeria, indicating a notable impact of climate change [39].

As climate changes further, extension of rainy seasons and amounts of rainfall are predicted in the region, this might lead to increase exposure to fungi hypersensitivity. Increasing temperatures may also be expected to influence the growing season of plants and fungi, and hence influence the timing and quantities of pollen released, given that many allergenic species are already 
present in the region. To reduce the health burden due to impact of climate change on airborne pollen and spores, adaptive strategies such as immunotherapy should be developed and implemented.

\section{CONCLUSION}

Airborne pollen and spores are major component of ambient atmosphere and their quantity depends on phenological activities and influence of weather parameters. In the study area, anemophilous pollen and some hydrophilic fungi were more dominant and could be responsible for triggering and exacerbations of allergenic diseases within the study period. Climate variability tends toward increase in the length and intensity of rainy season which could favour more fungal spores preponderant in the ambient atmosphere in Nsukka, Nigeria.

\section{ACKNOWLEDGEMENT}

The present study was carried out during my postdoctoral fellowship in Muhimbili University of Health and Allied Science, Tanzania, a program sponsored by Association of Commonwealth Universities (ACU) in collaboration with the African Academy of Science (AAS) on CIRCLE (Climate Impact Research Capacity and Leadership Enhancement Programme). We are grateful to the sponsors of the program and also very thankful to the staff of the Department of Environmental and Occupational Health, Tanzania for their hospitality, friendliness and collegiality. I appreciate my home institution, Ebonyi State University, Abakaliki for a one year relief from duties to undertake postdoctoral fellowship.

\section{REFERENCES}

1. Singh A.B. and Mathur C., 2012. An aerobiological perspective in allergy and asthma. Asia Pac Allergy 2(3):210-222.

2. Burge H. A. and Rogers C.A., 2000. Outdoors Allergens. Environmental Health Perspective 108 (4): $653-659$.

3. Nolte H., Backer V. and Porsberg C., 2001. Environmental factors as a cause for the increase in allergic disease. Ann Allergy Asthma Immunol 87:7-11.

4. Shahali, Y., Majd, A., Pourpak, Z., Tajadod, G., Haftlang, M.,\&Mostafa, M., 2007. Comparative study of the pollen protein contents in two major varieties of Cupressusarizonica planted in Tehran. Iranian Journal of Allergy, Asthma and Immunology, 6(3), 123-127.

5. Horner, W.E., Helbling, A., Salvaggio, J.E. and Leher, S.B. 2000. Fungal Allergens. Clinical Microbiology Reviews 8: 161179.

6. D'Amato, G., Liccard, G., D'Amato, M. and Cazzola, M. 2002. Respiratory allergic diseases induced by outdoor air pollution in urban areas. Respiratory Medicine 57(3-4): 161-163.

7. Denning D. W., Pashleyl C., Hartl D., Wardlaw A., Godet C., Giacco S.D.,Delhaes L. and Sergejeva S. ,2014. Fungal allergy in asthma- state of art and research needs. ClinTransl 4: 14. doi: 10.1186/2045-7022-4-14

8. Burge, H. A. , 1995. Bioaerosols: Indoor Air Research Series. Lewis Publisher, New York, Washington, D. C., London. 109pp.

9. Zukiewicz-Sobezak W. A., 2013. The role of fungiin allergic diseases. Postepy Dermatol Alergol 30(1) 42-45

10. Adeyemi A. S., Akinboro A.O., Adebayo P.B., Tanimowo M.O. and Ayodele O.E, 2015. The prevalence, Risk factors and changes in symptoms of self-Reported Asthma,Rhinitis and Eczema among pregnant women in Ogbomoso, Nigeria. J. Clin. Diagn Res 9(9):0001-0007

11. Cecchi L. D., D’ Amato G., Ayres J. G., Galan C., Forastiere F., Forsberg B., Gerritsen J.,Nunes C., Behrendt H., Akdis C., Dahl R and Annesi- Maesano I. , 2010. Projections of the effects of climate change on allergic asthma: the contribution of aerobiology. Allergy 65:1073-1081

12. Singh, A. B. and Shahi, S., 2008. Aeroallergens in clinical practice of allergy in India. ARIA Asia Pacific Work-Shop report. Asian Pacific Journal of Allergy and Immunology 26: 245-256.

13. Albertine, J.M., Manning W.J., Dacota, M., Stinson K.A., Mullenberg M.L. and Rogers C.A., 2014. Projected carbon dioxide to increase Grass pollen and Allergen Exposure Despite Higher ozone levels. Plos a (11):e 111712

14. Di-Giovanni, F., Kevan, P. G., Nasr, M. E. (1995). The variability in settling velocities of some pollen and spores. Grana, 34(1): 39-44.

15. Twaroch T. E., Curin M., Valenta R. and Swoboda I., 2015. Mold Allergen in Respiratory Allergy: from structure to Therapy. Allergy Asthma Immunol Res 7(3) 205-220.

16. Ziska, L. H. Epstein P. K. and Schlesinger W. H., 2007. Rising $\mathrm{Co}_{2}$, Climate Change and Public: Exploring the links to plant Biology. Environ Health Perspect 117(2): 155-158.

17. Prieto-Baena J.C., Hidalgo P.J., Dominguez E. and Galan C., 2003. Pollen production in the Poaceae family. Grana 42:153159.

18. IPCC, 2013: The Physical Science Basis. Contribution of Working Group 1 to the Fifth Assessment Report of the Intergovernmental Panel on Climate Change.

19. Ariano R., 2009. Climate change and increase of allergic diseases. Eur Ann Allergy ClinImmunol (41) $136-138$.

20. Tosunoglu A., Babayigit, S. and Bicaku, A., 2014. Aeropalynological survey in Buyukorhan, Bursa. Turkish Journal of Botany 38 : 1404- 1416.

21. Desalu O.O., Salami A.K., Iseh K.R. and Oluboyo P. O.,2009. Prevalence of self-reported allergic rhinitis and its relationship with asthma among adult Nigerians. J. Investig Allergol Clin Immunol 19(6):474-480

22. Oni A. O., Erhabor G. e. and Egbagbe E.E., 2010. The Prevalence, management and Burden of Asthma. A Nigerian study. Iran J. Allergy Asthma Immunol 9(1):35-41. 
23. Oladeji, S.M., Nwawolo C.C. and Akinola O.O., 2015. Prevalence of Allergic disorders among University Students in a Tertiary Institution in Nigeria. IOSR Journal of Dental and Medical Sciences 14:12-16.

24. Njokuocha, R.C. (2006). Airborne pollen grains in Nsukka, Nigeria. Grana45: 73-80.

25. Ezike, D. N., Nnamani, C.V., Ogundipe, O.T. and Adekanmbi O. H.,2016. Airborne pollen and fungal spores in Garki, Abuja (North-Central Nigeria). Aerobiologia 32(4): 697-707.

26. Jones G. D., 2014. Pollen analysis for pollination research, Acetolysis. Journal of pollination Ecology 13(21):203-217.

27. Y'bert, J. P.,1979. Atlas des pollen de cote d'Ivoire. Paris: Orstom

28. Agwu, C. O. C., \&Akanbi, T. O.,1985. A palynological study of honey from four vegetation zones of Nigeria. Pollen et Spores 27, 335-348.

29. Agwu, C. O.C. and Osibe E.E.,1992. Airborne palynomorphs of Nsukka during the months of February-April,1990. Nigerian Journal of Botany 5: 177-185

30. Ofomata, G. E. K., 1975. Nigeria in maps, Benin City: East. St. Athiope Publ. H

31. Ani V.A., Nzeako A.N. and Obianuko J. C., 2012. Energy optimization and datacentres in 2 different locations in Nigeria. International Journal of Energy Engineering 2(4)151-164.

32. Molina R.T.,Rodriguez A.M., Palaciso I. S. and Lopez F.G., 2009. Pollen production in anemophilous trees. Grana 35(1):3846.

33. Kohler E. and Lange E. A. 2009. Contribution to distinguishing cereal from wild grass pollen by LM and SEM. Grana 18: 133-140.

34. Prakashkumar P.M. and Ravinfran P., 1998. Studies on the allergenicity of nine tropical pollen allergens. Grana 37:185-188.

35. Menezes ,E. A., Trindade, E. C. P., Costa ,M. M., Freire C. C. F., Cavalcante M. D. S., Cunha, F. A., 2004. Airborne fung i isolated from Fortaleza city, State of Ceará, Brazil. Revista do Instituto de Medicina Tropical de São Paulo http://dx.doi.org/10.1590/S0036-46652004000300003

36. Fukutomi Y. and Taniguchi M. 2015. Sensitization to fungal allergens: Resolved and unresolved issue. Allergology International 64:321-331.

37. Dixit A., Lewis N., BatyJ.,Crozier W. and Wedner J. 200. Deuteromycetes aerobiology and skin -reactivity patterns: A two years concurrent study in Corpus Christi,Texa,USA. Grana 39: 209-218.

38. Nwaiwu I. O. U., Ohajianya D. O., Orebiyi J.S., Ibekwe U.C.,Lemchi, J. I. Onyeagocha S.U.O., Odoemena, B., Utazi, C. O., Osuagwu C. O. and Tasie C. M., 2014. Climate change trend and appropriate mitigation and adaptation strategies in South East Nigeria. Global Journal of Biology, Agriculture and Health Science 3(1) 120-125.

39. Odjugo, P.A., 2010. General overview of climate change impacts in Nigeria. J Hum Ecol 29(1): 47-55. 